\title{
Humanitarian knowledge in the age of digitization: challenges and results
}

\author{
Elena I. Zamaraeva ${ }^{1 *}$ and Aleksandr V. Naumov ${ }^{1}$ \\ ${ }^{1}$ Financial University under the Government of the Russian Federation, Department of Humanities, \\ Moscow, Russia
}

\begin{abstract}
This article is devoted to the challenges faced by humanities education in the age of global digitization. A precondition of the research is the antinomicity of the concepts of humanitarian knowledge and digitalization. The research objective is to confirm the significance of humanitarian knowledge in formation of conceptual thinking as a basic skill of intelligent activity in modern world. The research applied comparative analytical method, on the basis of which the features of formation of conceptual thinking in modern school and university were considered, the significance of humanitarian knowledge was substantiated as a basis of formation of conceptual thinking, as axiological basis of personal and civil education of students, formation of social intellect, patriotism, civil and personal responsibility. The features of the use of visual aids are analyzed as deforming method upon formation of conceptual thinking of modern students in the age of total digitization, as well as the experience of distance learning in humanities under the pandemic conditions. It is concluded that the humanitarian knowledge is the most important resource in formation of conceptual thinking as a basic component of intelligent development, socialization and fostering of civil and personal self-consciousness of students in higher school.
\end{abstract}

Keywords: digitization, humanitarian knowledge, conceptual thinking, social intelligence.

\section{Introduction}

Antinomicity of the concepts of digitization and humanitarian knowledge is a precondition of the research. Humanitarian knowledge is the knowledge of the intrinsically human in a person, bearing axiological settings and meanings. Digitization is not only application of hard- and software, but also replacement of human in certain areas, decision making without human involvement, substitution of human with artificial intelligence. The question arises: Why should a person need humanitarian knowledge in the age of total digitization?

Numerous studies are devoted to this problem. Most researchers substantiate the necessity of reinterpretation of the role of humanitarian knowledge in order to minimize the impact of modern ICT [1-8]. Some authors believe that humanitarian sciences are in the state of role uncertainty [9].

\footnotetext{
* Corresponding author: zamaraeva e@mail.ru
} 


\section{Methods}

The system analytic method allows hypothesizing priority of humanitarian knowledge in the age of digitization.

The established situation in higher school related with the collapse of the Soviet system of education, with unprecedented rates of digitization of all areas of our life, with the pandemic and transition to distance learning creates a set of challenges for the humanities education.

\section{Results}

From year to year there occurs decrease in intelligent and general educational level of former schoolchildren [10]. We work with students, who quite often poorly speak, are unable to formulate their thoughts, even poorly read. They cannot highlight the main and the secondary, do not understand cause-and-effect relationships, they have a very limited outlook.

This evidences that the conceptual thinking as a basis of abstract thinking is absent. Vygotsky wrote that only during studying basics the conceptual thinking was formed [11]. What is included into the conceptual thinking? What are its components?

1. Intuitive: highlighting of the main, significant.

2. Logical: determination of objective cause-and-effect relationships.

3. Conceptual and categorial: generalization, systematization.

Why it happens? The reforms of education of the 1990-s completely destroyed the Soviet system of school education. Graduating from school, a Soviet pupil obtained general education certificate, i.e., passed exams in the main disciplines, hence, had basic knowledge in these areas, had a coherent picture of world and human in this world. Besides, a mandatory component of the Soviet school was fostering the basic human values: respect for elders, prestige of knowledge and education, diligence, honesty, mutual support, etc.

In the Soviet schools and universities, science was at top of mind, the basics of the sciences were studied, because while studying sciences, conceptual thinking of pupil or student was formed. Formation of conceptual thinking, according to Vygotsky, is the main task of intellectual development of teenager, the zone of the nearest development [11].

Education is the most conservative area of life, which is changing so quickly that it is impossible to keep up. Therefore, the task of education is to teach humans to think, to form their conceptual thinking, then they will be able to orient in rapidly changing world, study further, work successfully, forecast, make conclusions, generalize, self-learn, i.e., live independently and work in their profession.

Thus, education should be based on the principle of scientific arrangement of information. This was mentioned in the works by Vygotsky, Davydov [11, 12]. If the conceptual thinking is formed, a human can solve any life or professional problem, analyzing possible consequences and making required conclusions.

Nowadays employers raise the alarm, appeal to psychologists, to scientific community with the most serious problem: university graduates cannot fully work, do not understand objectives and tasks, cannot generalize, forecast, analyze errors, do not understand causeand-effect relationships in various areas of professional activity.

Herewith, this alarm is risen by people of middle and senior age, young people do not have such concerns. Many of them, from the USE generation, have no idea that it is possible to think differently. Herewith, the surveys demonstrated that $78 \%$ of young people were satisfied with their level of education; only $6 \%$ of them were dissatisfied [13]. The book culture is being gone, reading is an overwhelming intellectual challenge for modern youth. According to the data by Levada Center, $47 \%$ of young people do not read books at all [13]. 
The humanitarian knowledge should support significant objective: attempt to generate what the comprehensive school did not do, that is, to form conceptual thinking in the frames of knowledge. Humanities not only form categorial apparatus, build the pyramid of scientific knowledge, but also form coherent picture of world, ability to highlight the most significant, cause-and-effect relationships, to generalize, to systematize, to make conclusions. If conceptual structures have not been formed, then the human does not notice errors, the illogical pattern of theoretical constructions, meets difficulties while checking or substantiating own conclusions, which do not lead to required practical result [14].

The foundation of human attitude to the world is the system of values. It is the humanitarian knowledge that forms spiritually mature and full individual, since all basic categories of humanitarian sciences are presented via the prism of values. Socrates's virtue, Plato's good, Kant's categorical imperative, Solovyov's all-oneness... Not only competences are formed but honor, dignity, justice, compassion are fostered. In order to solve problems, conscience, for instance, is not required. But it is impossible to cognize the meaning of action without conscience [8: 9].

At present, historical memory is often mentioned, but falsification of history is possible, when no critical thinking of people is formed, they cannot correlate facts and make conclusions due to the lack of formed conceptual thinking. Primarily, humanities education fosters citizens, patriots. The societal security of the Russian homeland depends on whether the students will be the citizens of our country, nationally oriented elite.

Humanitarian knowledge implies formation of social intelligence, which is a system of adaptation skills and abilities allowing a human to be socially successful, including ability to understand motives of actions of other humans, and to analyze own actions, as well as to behave adequately under various situations; this is success in interpersonal communications, social maturity, ability to bear responsibility.

Digitization became a part of our life, its rates are so rapid that the question arises: will the humans be able to control this new reality? will there be any room left at all for a human being? Digitization leads to reformation of traditional system of education.

Refusal from classic lecture format in universities leads to formation of pre-conceptual, children's thinking oriented at visual aids. Davydov has in his works proved that a specific image fixed in memory interferes with development of notions, the principle of visibility does not form theoretical and then abstract thinking; a student, as a preschool child, thinks from the particular to the particular, does not derive general regularities [12]. Wide-spread interest to presentations, gamification kills conceptual thinking and forms defective one.

Online learning during the pandemic has demonstrated that distance learning is not an independent but a supplemental form of education, it can be used in exclusive cases so that not to interrupt completely the educational process. Only highly-motivated students can study online, their number is always limited. During distance learning there is no competition element, face-to-face contact, socialization, there is no boundary between studying and recreation. The performed studies demonstrated that $83.8 \%$ of pupils demonstrated adverse mental responses of marginal level [15].

Only a personality can educate a personality. How can this be transmitted in distant format? And the humanitarian knowledge is not just knowledge, it is upbringing and formation of values and meanings. Wisdom does not depend on the degree of technical conquest of the world [16].

The result of this work is the hypothesis that in the education system of Russia, the humanitarian knowledge should be prioritized as a mandatory component in the structure of higher education, which is responsible for formation of conceptual thinking of students in the age of wide-scale digitization. 


\section{Conclusion}

Therefore, it can be concluded that the humanitarian knowledge is not only the basic resource for formation of conceptual thinking but also a prioritized trend in modern education as a tool of preservation of societal security of Russian society under the conditions of digital turbulence.

\section{References}

1. N.A. Moiseeva, A.G. Shipilov, L.V. Bochkova, Rol' gumanitarnogo znaniya v epokhu tsifrovizatsii [The role of humanitarian knowledge in the era of digitalization], in Proceedings of 11th International Scientific and Practical Conference of Teachers of Higher Education Institutions Rossiya v Menyayushchemsya Mire: Traditsii i Innovatsii [Russia in a Changing World: Traditions and Innovations], 29 November 2019, Russian State Agrarian Correspondence University, Balashikha, Russia (2019)

2. A. Guryanova, A. Timofeev, Bulletin of the Moscow Region State University. Series: Philosophy, 3, 70-76 (2020). https://doi.org/10.18384/2310-7227-2020-3-70-76

3. V. P. Berkut, Y. V. Bondareva, T. A. Kostyukova, V. P. Maikova, E. M. Molchan, V. A. Pesotsky, Modern Journal of Language Teaching Methods, 8(5), 263-281 (2018)

4. A. V. Guryanova, E. Khafiyatullina, M. Petinova, N. Astafeva, N. Guryanov, Lecture Notes in Networks and Systems, 87, 244-250, (2020)

5. I.D. Afanasenko, V.V. Borisova, Bulletin of the St. Petersburg State University of Economics, 5(113), 7-11 (2018)

6. A.M. Factor, S.G. Kamolov, A.A. Nikandrova, Modeling, Optimization and Information Technology, 6(2), 86-103 (2018)

7. E. V. Bestaeva, Humanities and Social Sciences. Bulletin of the Financial University, 10(4), 80-84 (2020). https://doi.org/10.26794/2226-7867-2020-10-4-80-84

8. A.G. Tyurikov, A.Ya. Bolshunov, Humanities and Social Sciences. Bulletin of the Financial University, 9(2), 6-10 (2019). https://doi.org/10.26794/2226-7867-2019-9-26-10

9. S.V. Gerasimov, Humanities and Social Sciences. Bulletin of the Financial University, 10(3), 52-57 (2020). https://doi.org/10.26794/2226-7867-2020-10-3-52-57

10. N.A. Orekhovskaya, Vysshee Obrazovanie v Rossii, 3, 135-139 (2014)

11. L. S. Vygotsky, Thought and language (translated and edited by Eugenia Hanfmann and Gertrude Vakar) (The MIT Press, Cambridge, MA, 1962)

12. V.V. Davydov, Teoriya razvivayushchego obucheniya [Developmental learning theory] (INTOR, Moscow, 1996)

13. L. Gudkov, N. Zorkaya, Ye. Kochergina, K. Pipiya, A. Ryseva, The Russian Public Opinion Herald. Data. Analysis. Discussions, 1-2(130), 21-121 (2020). Accessed on: December 20, 2020. [Online]. Available: https://www.levada.ru//cp/wpcontent/uploads/2020/08/vom1-2020.pdf

14. L.A. Yasyukova, Zakonomernosti razvitiya ponyatiynogo myshleniya i yego rol' v obuchenii [Patterns of development of conceptual thinking and its role in learning] (IMATON, Saint Petersburg, 2005)

15. V.R. Kuchma, A.S. Sedova, M.I. Stepanova, I.K. Rapoport, M.A. Polenova, S.B. Sokolova, I.E. Aleksandrova, V.V. Chubarovskiy, Journal "Problems of School and University Medicine and Health", 2, 4-24 (2020) 
16. P. Sloterdijk, Critique of cynical reason (University of Minnesota Press, Minneapolis, 1988) 